\title{
Decadal Trend Analysis of Land Use Changes (1980 - 2020) in the Calabar River Basin, Southern Nigeria
}

\author{
Abali, Temple Probyne \& Aminigbo, Leonard Onyinyechi Michael \\ Department of Geography and Environmental Management \\ Faculty of Social Sciences Rivers State University, Nigeria \\ Email : temple.abali@ust.edu.ng
}

\begin{abstract}
The necessity for a platform for diverse geo-spatial investigations in the study area prompted this study. Using a Geographic Information System (GIS) analysis, the study looked at land use trends over a 30-year period (19802010). Urban and farm land use types encroached on grassland, forest, bareland, and waterbody by 17.54 percent and 13.59 percent, respectively, with losses in grassland, forest, bareland, and water bodies of 12.01 percent, 11.01 percent, 4.62 percent, and 3.5 percent. As a result, maps/charts of land use changes in the study area have been created, revealing a rapidly deforested region for urbanization and agricultural operations. This result will offer planners and decision-makers with a quick assessment of the possible impact of human activities in the study region, as well as the commencement of relevant efforts to reduce the impact. Furthermore, because it has provided accurate information related to land use changes over time, it will yield valuable information for the analysis of the environmental impacts of population pressure, agriculture, urban expansion, resettlement program, climate change, resources managers, development agents, fund providers, socio-economic development planners, public administrators, and environmentalists.
\end{abstract}

Keywords: GIS, geospatial, land use change, land cover, river basin, urbanization.

\section{Introduction}

Due to changing land use/cover pattern, the coastal environment has aroused the interest of both researchers and policymakers. Land is under great strain as a result of the world's everincreasing human population and desire for agriculture (Cunningham, Cunningham and Siago, 2005). Because of the opportunities for residential, industrial, agricultural, recreational, and commercial land use development, the coastal belt has seen tremendous population growth (Oyegun, 1993). Concerns about land use change first surfaced in the global environmental change study agenda some decades ago, as scientists realized that land use changes cause climate and soil degradation (Otterman, 1974; Charney and Stone, 1975; Sagan, Toon and Pollack, 1979). Since the International Geosphere and Biosphere Programme (IGBP) and the International Human Dimension Programme (IHDP) on global environmental change began their main project on the realm of study in the mid-1990s, there has been growing awareness of this area of research" (Turner, Skole, Sanderson, Fischer, Fresco, Leemans, 1995; Lambin and Geist, 1999).

Unprecedented land use changes had occurred in Nigeria in general and Calabar in particular. The majority of changes in vegetation and rural land use occur in the tropics, according to Ayoade (1988). Because of the limits imposed by the Calabar River, Great Kwa river estuary, and the wetlands of the Cross River estuary, Efiong (2011) witnessed a significant transfer of land development from the eastern and southern areas of the city to the northern part of the State. For instance, the National Integrated Power Project (NIPP) is making use of large expanses of land at Ikot - Nyong in Odukpani; Pamol Rubber Plantation and Tinapa Leisure 
Resort in Odukpani and Municipality respectively and is situated along the Calabar-Itu highway of the study area.

There are continuous economic activities carried out on these lands by man which have affected the land use pattern of the area. Despite these activities, there is no evidence of ecological attention by the government to improve the environment in the region. Okude (2006) noted of the existence of dearth of literature and also, low level of recognition on the ecological dimensions of land use studies in Nigeria. The linkbetween Calabar river basin directly or indirectly determines what happens in Calabar the State Capital of Cross River State which is the host to major African Leisure Resorts. The rapid rate of deforestation is further accompanied by urban expansion due to diverse human activities in the region. The trend explains the significant land use changes experienced in the study area overtime. Jackson, Hart, Adekunle and Nkwunonwo (2012) noted that in every coastal environment, expansion of an urban/residential area over a period of time encroaches on other land uses such as farmland, water body, swamp/mangrove, grassland, bareland, forest etc.

There are various forms of change detection applications that have been tested, and executed in different study areas; the result indicated no significant answer. This study employed the visual analysis based on map-to-map comparison method which is commonly used for land change detection. This method has been adopted and supported by Sadar and Winne (1992); Sunar (1998); Ulbricht and Heckendorff (1998); Stone and Letebvre (1998) among others. Several other studies had been conducted in the area of land use change/cover in Nigeria (Omojola, 1997; Bisong, 2007; Ekpeyong, 2008; Idoko, Bisong, Bisong and Okon 2008; Igbokwe, Akinyede, Dang, Alaga, Ono, Nnodu and Anike, 2008; Nduji, Nnam and Ekpete, 2012 etc). In all such studies, the conclusion was that urban/residential land use overrides the land use change pattern.

In view of the above facts, Calabar river catchment follows a trend of land use change / cover pattern because the region is rapidly being urbanized. Accordingly, this study seeks to answer the following research questions:

1. What are the major land use types of the study area?

2. What is the trend of land use changes in the study area overtime?

3. What is the impact of the changes in land use / cover on the livelihood of the inhabitants?

4. What are the remedies / mitigation measures to land use changes / covers?

\section{AIM AND OBJECTIVES}

The aim of this study is to examine the dynamics of land use changes and covers in Calabar river catchment, Cross River State, Nigeria. To achieve the aim above, the specific objectives are to:

1. Identify the major land use types of the study area.

2. Determine changes in the land use pattern of the study area overtime.

3. Unravel the impact of the changes in land use on the livelihood of the inhabitants.

4. Proffer solutions to the changes in land use / cover. 


\section{Literature Review}

The study area, located in southern Nigeria lies between Latitudes $4^{0} 45^{1} \mathrm{~N}$ and $5^{0} 10^{1} \mathrm{~N}$ and Longitudes $8^{0} 05^{1}$ and $8^{0} 45^{1} \mathrm{E}$ (Fig. 1). It is within the Hydrological Boundary of the Calabar River system. It is a fourth-order river catchment with an estimated area of $460 \mathrm{~km}^{2}$. It is a low land underlain by coastal plain sands of Benin Formation. The mean annual temperature remains about $27^{\circ} \mathrm{C}$ throughout the year and, with a total rainfall of about $300 \mathrm{~cm}$. The relative humidity is estimated to reach about $90 \%$. while acquisition according to Thomas and Amaechi is the act of setting new knowledge and skills that can be transferable from one person to another. Ezeji and Okorie in Anaele (2018) noting the importance of skills acquisition in national development averred that the nation's socio-economic problems will be ameliorated when people are given adequate vocational skill. Vocation as defined by Anaele (2018) is an occupation or trade which is practiced by an individual in order to earn a living. While vocational skills is defined by Ojingwa (2018) as the process of making superlative output and the general characteristics of one's behavior in a given field. Vocational skills are skills that focuses on specific trade with a hands-on approach, in areas such as agriculture, health or construction as well as general employment skills (Revermann, 2015). Human Capital Theory in Inyang and Agwadu (2017) best explains vocational skills acquisition as the sure therapy to check raging poverty as well as stimulate rapid socio-economic development of the rural poor.

Kabiru (2016) defined infrastructure as the basic facilities that are essential for the development of a nation. Kabiru described infrastructure as the final consumption item by households and as intermediate consumption item for firms. World Development Report in Goel (2002) categorized infrastructure into economic and social infrastructure. Economic infrastructure according to World Development Report includes services such as electricity, transportation, water system, communication, irrigation, energy, financial institution amongst others while social infrastructure includes services such as hospitals, schools, housing, correctional facilities amongst others. Availability of infrastructures be it social or economic according to World Bank Report in Goel (2002) significantly influences development, especially in rural communities. Also, infrastructure provision enhances the production and distribution network of key sectors in the economy as well as promotes overall economic growth.

International Labour Organization in Nwafor (2018) described youth as an individual with full life promise, energy and aspiration between childhood and adulthood. Youths need to develop and acquire necessary skills to enable them meet the challenges of particular jobs, aspirations as well as prepare for higher responsibilities and for future needs. Okoye (2017) noted that the solution to youth unemployment in Nigeria is vocational sills acquisition and practice. When youths are skillful in life, the chances of associating themselves with social vices will not be there. Dada (2007) states that practical work contributes in molding the mind of youths. According to Ekesionye and Okolo (2012), youth empowerment and their full participation is the basis of equity in all spheres of society such as access to power, land, credit are fundamental for the achievement of equality, peace and societal development. Empowerment of youths could mean encouraging youths to be self-reliant, economically independent, having positive selfesteem, generating confidence to face any difficult situation and incite active participation in various socio-economic and political endeavors. The benefits derived from any empowerment programme must not only be relevant to the needs of the intended beneficiaries but efforts must 
be made to ensure the target population is also able to retain the benefits which is particularly significant to youths.

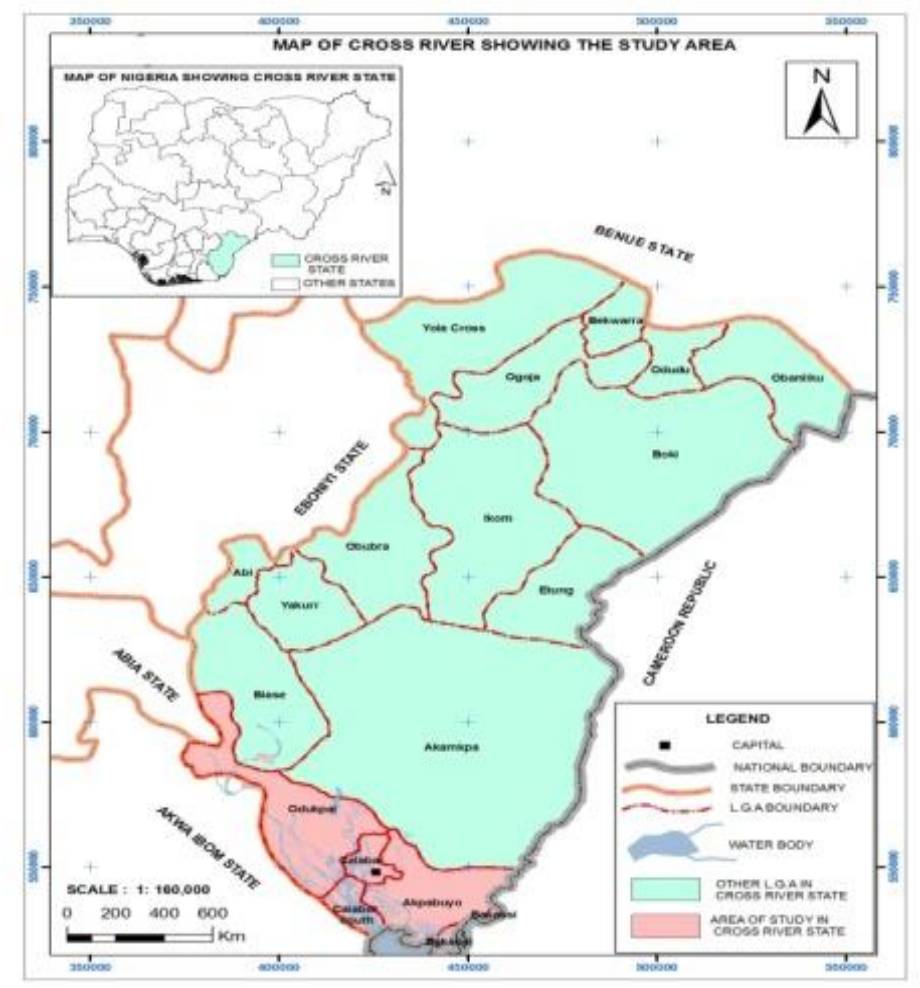

\section{Research Method}

Land use activity of the basin of the study area integrated data collected through available topographical map and aerial photographs. This served as a basis for interpretation and comparison of the change of the different land use types in the study area. The satellite imageries' interpretation of the study area covered four epochs: 1980, 1990, 2000 and 2010 on a scale of 1:500,000. The study also integrated the available topographical map of the study area on a scale of 1:160,000.The study adopted data from different sources and used different methods and approaches to analyze the long term land use/cover changes and trends in the four decades of the study area. The approaches included imageries from different satellites (Landsat), multi-temporal dates (MSS 1980, TM 1990, ETM 2000 and ETM+ 2010), fieldwork surveys and forest inventory application. Pixel-based classification was applied as a new approach of imagery classification. The Earth Resources Data Analysis System (ERDAS) version 9.1 and Integrated Land and Water Information System (ILWIS) software version 3.7 were used for imageries processing and masking and classification. Meanwhile, ArcGIS was employed for database development, spatial data analysis, and producing thematic maps and SPSS were used for statistical analysis. Coordinates of different locations in the study area were obtained by the use of a GPS using the WGS 84 32N Minna Datum.

Landsat satellite imagery of the study area was acquired for four epochs: 1980, 1990,2000 and 2010 from Global Land Cover Facilities (GLCF) and U.S.G.S. (United State Geological Survey).The approach includes imageries from different satellites (Landsat), multi-temporal data such as Landsat 1-5, the Landsat Multi-Spectral Scanner) $60 \mathrm{~m}$ resolution in multispectral (MSS1980), Landsat TM 1990 (Landsat 4 and 5 Thematic Mapper) 30m resolution in 
multispectral (TM 1990), Landsat 7 Enhanced Thematic Mapper 30m resolution in multispectral (ETM 2000) and Landsat ETM + 2010 (Landsat Level1 Enhanced Thematic Mapper Plus) 30m resolution (ETM+2010). Consequently, six land use types with varying degrees of changes were identified. They include water bodies, forest, bare, urban, farm, and grass surfaces.

\section{Findings and Discussions}

Below is the result of Land use / cover classification (Figs. 2 - 6), (Plate 1), summary table of results (Table 1) and statistical information (Figs. 7 - 10).

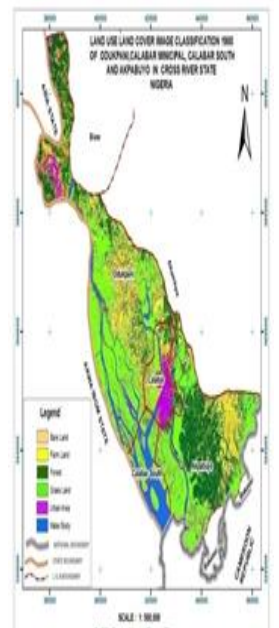

19-2 -

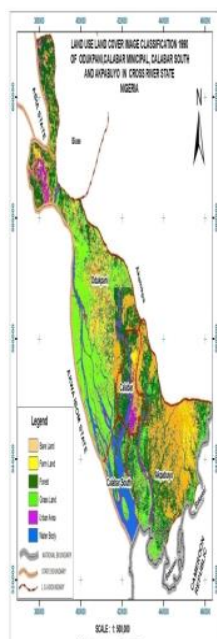

$2113:-3$

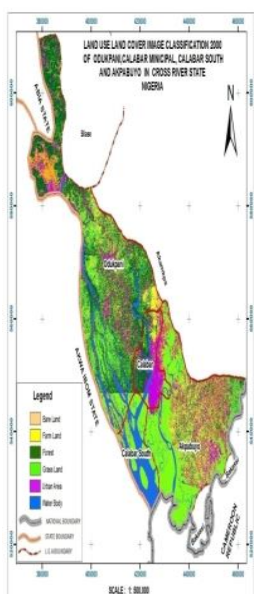

$20 x^{2}-2$

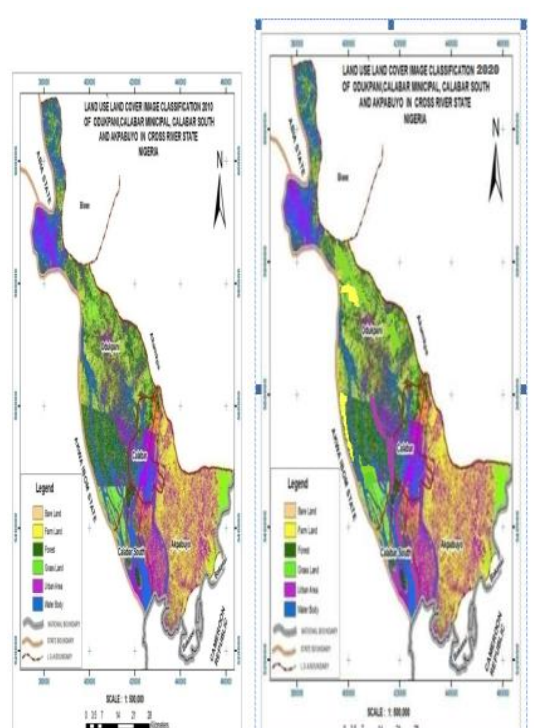

Fig. 2: LU/LC 1980 Fig.3: LU/LC 1990 Fig. 4: LU/LC 2000 Fig. 5: LU/LC 2010 Fig. 6: LU/LC 2020

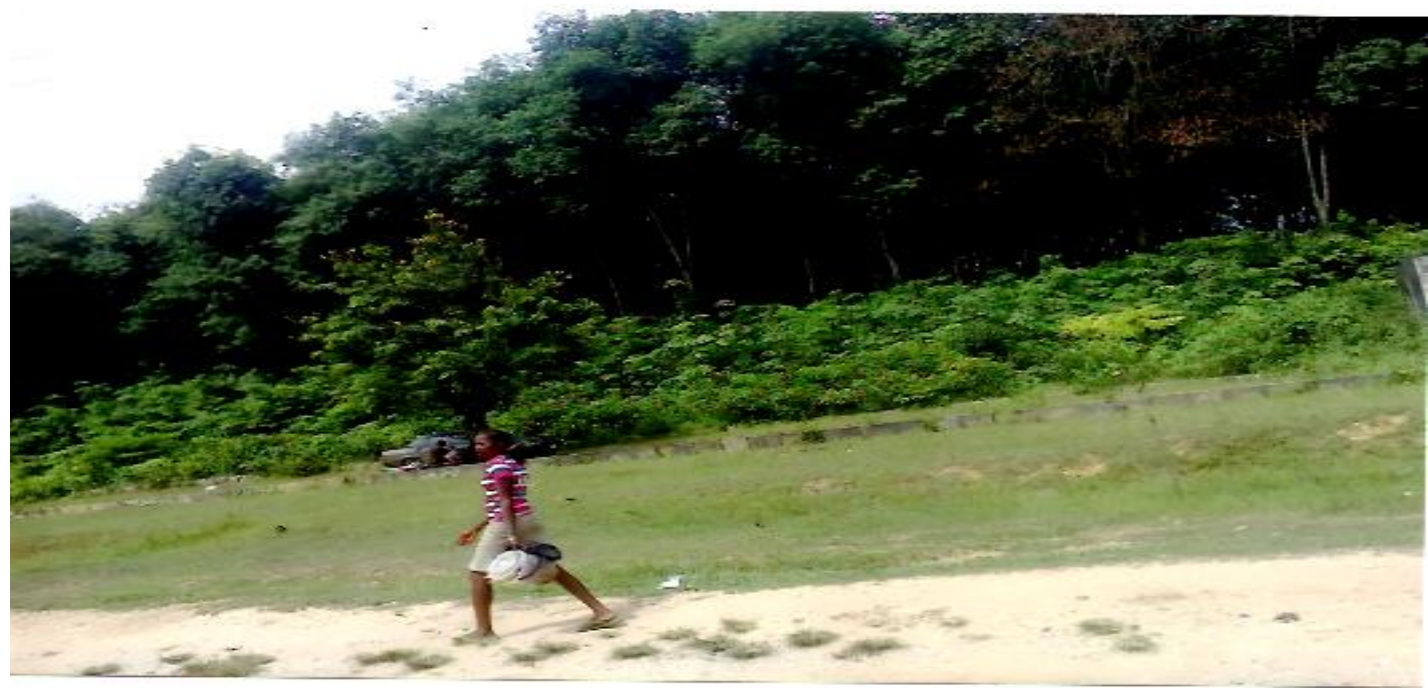

Plate 1: Urbanized (concretized), bare, grass, farm and forest surfaces side by side along Calabar - Itu Highway of the study area. 
Table 1: Summary of Land use Change Category at Different Epochs (1980 - 2020) in the Study Area

\begin{tabular}{|c|c|c|c|c|c|c|c|c|c|c|}
\hline \multirow{2}{*}{$\begin{array}{l}\text { Landuse } \\
\text { Change } \\
\text { Category }\end{array}$} & \multicolumn{2}{|c|}{1980} & \multicolumn{2}{|c|}{1990} & \multicolumn{2}{|c|}{2000} & \multicolumn{2}{|c|}{2010} & \multicolumn{2}{|r|}{2020} \\
\hline & $\begin{array}{c}\text { Area } \\
\left(\mathbf{m}^{2}\right)\end{array}$ & $(\%)$ & $\begin{array}{c}\text { Area } \\
\left(\mathbf{m}^{2}\right)\end{array}$ & $(\%)$ & $\begin{array}{c}\text { Area } \\
\left(\mathbf{m}^{2}\right)\end{array}$ & $(\%)$ & $\begin{array}{c}\text { Area } \\
\left(\mathbf{m}^{2}\right)\end{array}$ & (\%) & $\begin{array}{c}\text { Area } \\
\left(\mathbf{m}^{2}\right)\end{array}$ & $(\%)$ \\
\hline Water & & & & & & & & & & \\
\hline bodies & 205098300 & 8.77 & 136590300 & 5.84 & 128119500 & 5.48 & 123402600 & 5.27 & 4.98 & 1196038620 \\
\hline Urban & 74699100 & 3.19 & 173699100 & 7.42 & 271471500 & 11.60 & 485040600 & 20.73 & 23.99 & 5753254310 \\
\hline Grass & 577357200 & 24.68 & 574892100 & 24.57 & 583918200 & 24.96 & 296449200 & 12.67 & 11.48 & 2752264560 \\
\hline Farm & 238747500 & 10.20 & 283138200 & 12.10 & 282449700 & 12.07 & 556709400 & 23.79 & 25.12 & 6025165400 \\
\hline Forest & 838700100 & 35.85 & 705433500 & 30.15 & 606020400 & 25.90 & 581134500 & 24.84 & 23.06 & 5532260170 \\
\hline Bare & 405070200 & 17.31 & 465919200 & 19.91 & 467693100 & 19.99 & 296936100 & 12.69 & 11.36 & 2724395340 \\
\hline Total & $\begin{array}{l}233967240 \\
\text { 0 }\end{array}$ & 100.00 & $\begin{array}{l}233967240 \\
\text { 0 }\end{array}$ & $\begin{array}{l}100.0 \\
0\end{array}$ & $\begin{array}{l}233967240 \\
\text { 0 }\end{array}$ & 100.00 & $\begin{array}{l}233967240 \\
0\end{array}$ & 100.00 & 100.00 & 23983378400 \\
\hline
\end{tabular}

Source: Geographic Information System (GIS)

The initial records of land use changes / covers obtained in 1980 revealed in table above shows that water bodies occupied $8.77 \%$, urban area (3.19\%), grassland $(24.68 \%)$, farmland $(10.20 \%)$, forest $(35.85 \%)$ and bare land $(17.31 \%)$ of the total land area. The summary result shows that forest was the dominant land use type. Urban land use was the least recorded within the period (Fig. 7).

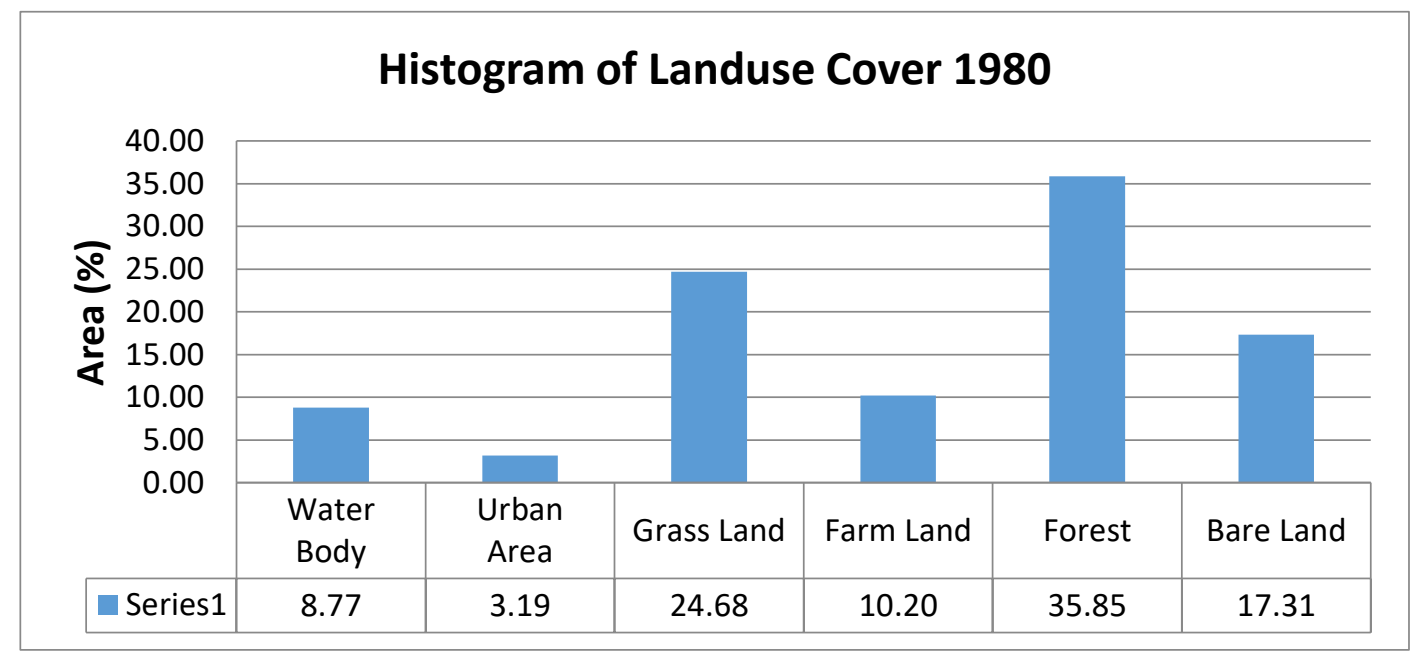


By 1990, urban land use type had increased by $7.42 \%$ and then expanded / encroached on farmlands, bare surfaces, water body and the surrounding secondary forest. Within the period; mangrove swamp, forest, bare surfaces, farmlands had reduced significantly (Fig. 7).

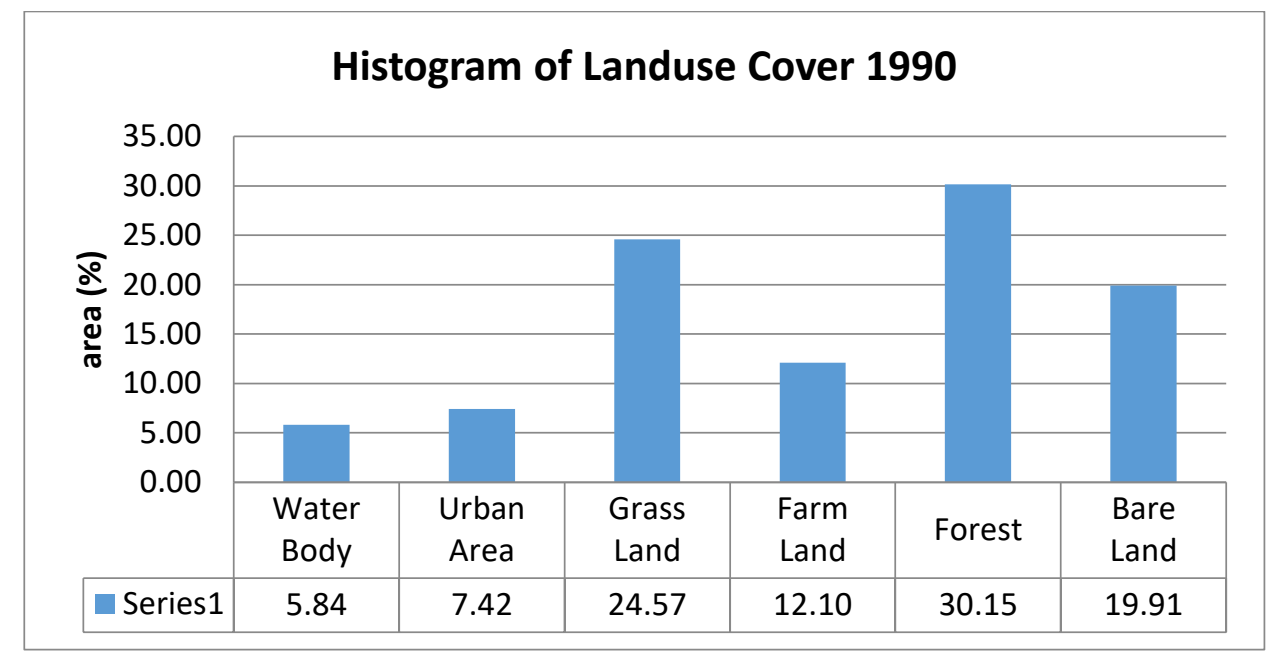

Fig. 7: Histogram of Land use Cover (1990) of the Study Area

By 2000, urban land use had increased by $11.60 \%$ and then expanded / encroached on farmlands, bare surfaces, water body and the surrounding secondary forest. Within the period mangrove, bare surfaces and forest had reduced (Fig. 8).

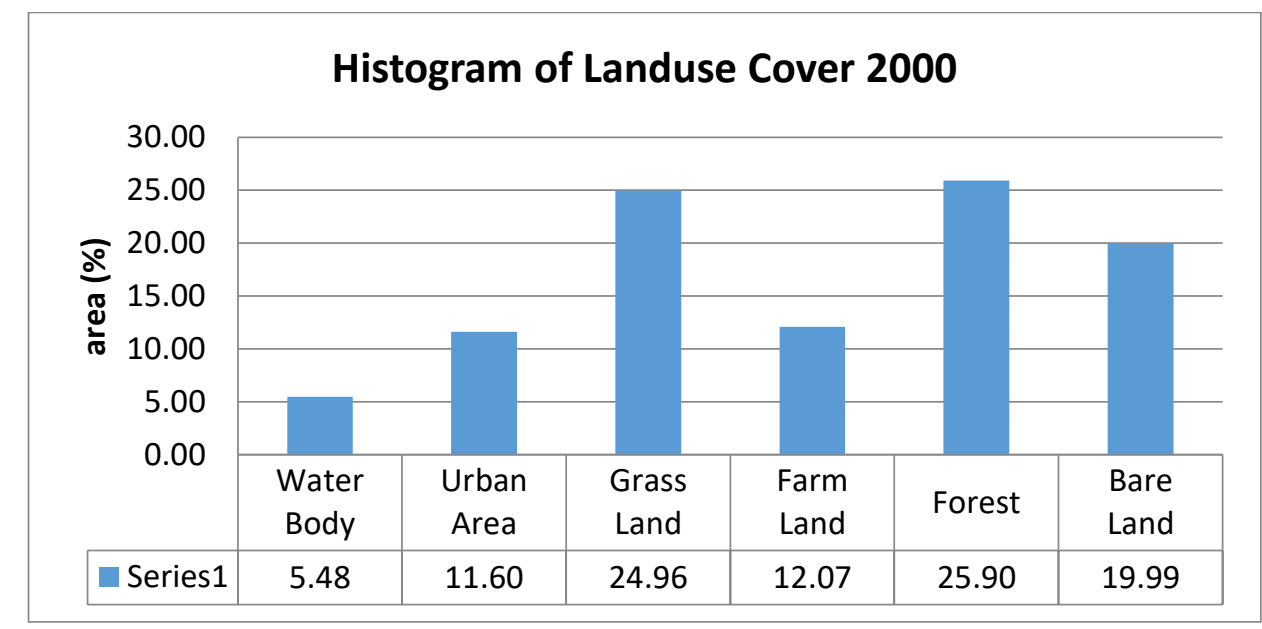

Fig.8: Histogram of Land use Cover (2000) of the Study Area

By 2010, urban land use had increased by $20.73 \%$ and then expanded / encroached on farmlands, bare surfaces, water body and the surrounding secondary forest. Within the period; mangrove and forest had reduced significantly (Fig. 9). 


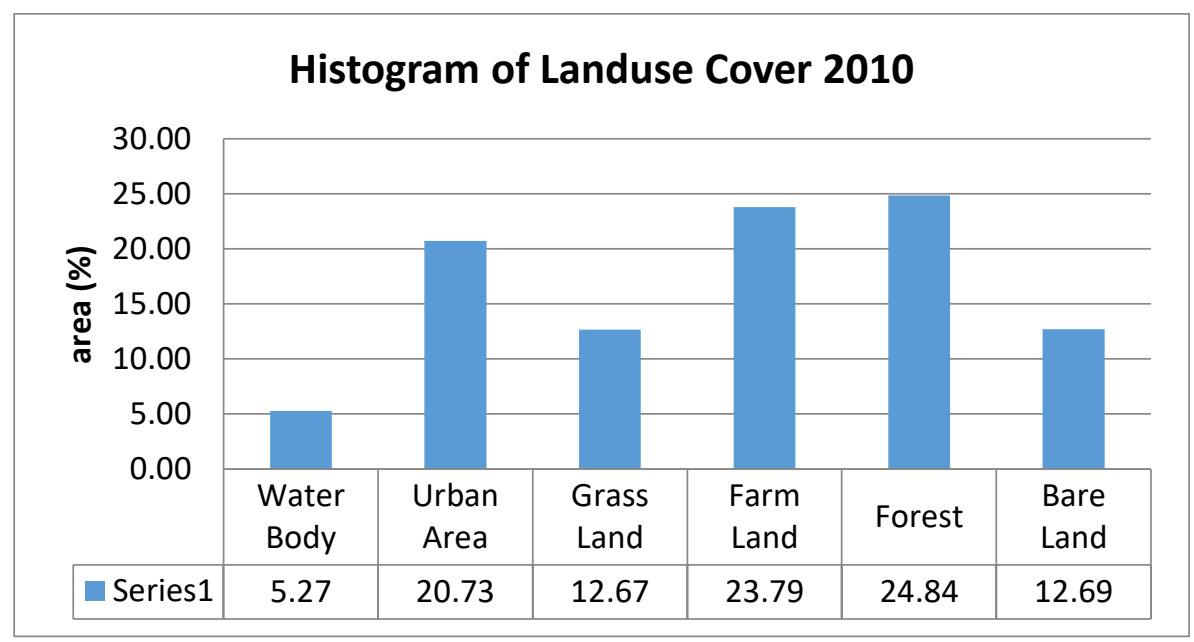

Fig.9: Histogram of Land use Cover (2010) of the Study Area

By 2020, urban land use had increased by $23.99 \%$ and then expanded / encroached on farmlands, bare surfaces, water body and the surrounding secondary forest. Within the period; mangrove and forest had reduced significantly (Fig. 10).

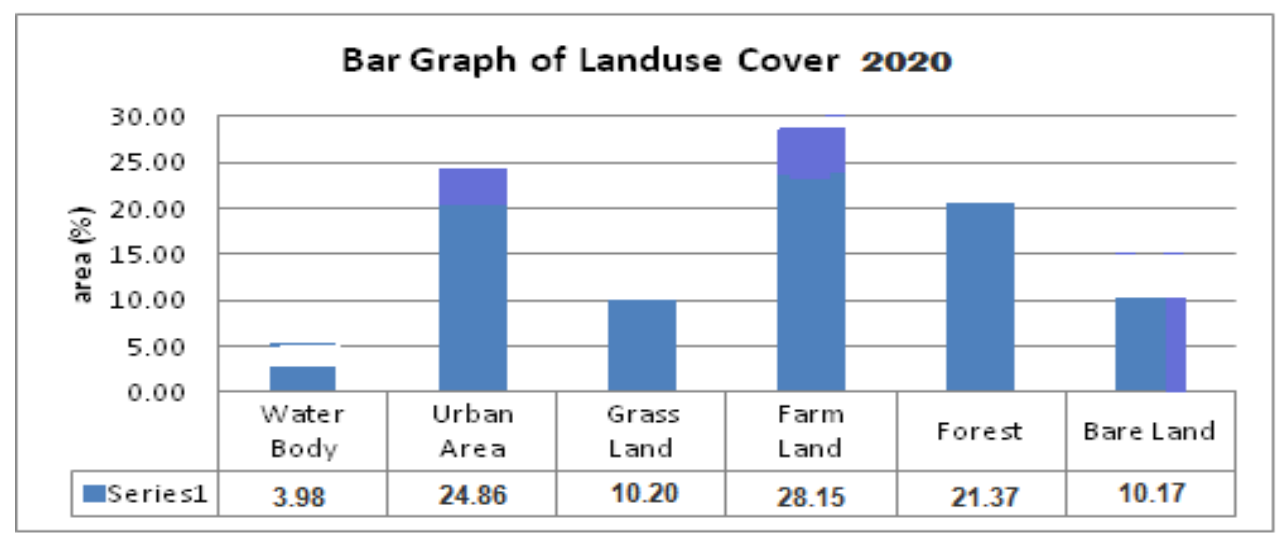

Fig. 10: Histogram of Land use Cover (2020) of the Study Area

\section{Conclusion}

The dynamics of the land use and land cover in Calabar River Catchment has been attributed mostly to increasing urbanization. Urban land type plays the dominant role in the land use change pattern in the region. This means that Calabar river catchment is increasingly being urbanized while at the same time engagement of the inhabitants in agriculture as a major economic activity. In the study area, within a 40 year period (1980-2020), the result of land use changes showed that urban land use type encroached on farmland, grassland, bare land, water bodies and grassland significantly.

\section{References}

River Catchment, Cross River State. Ph.D Thesis, University of Port Harcourt.

Ayoade, J.O. (1992). Introduction to Climatology for the Tropics. Ibadan: Spectrum Books.

Balogun, P. (1994): The impact of Social and Economic Issues on Forestry in Cross River State, Nigeria,Calabar: Cross River Forestry Department. 
Cross River State Forestry Commission (1988, 1990, 2000, 2001 and2003). Annual Report. Calabar: Forestry Commission.

Dunn, J. (1994): An Overview of Agroforestry in Cross River State. Cross River Forestry Project (ODA Assisted), Calabar.

Ede, P. N (2002). Correlates of Sediment Loss Over Land use Types in Port Harcourt. Ph.D Thesis, University of Port Harcourt.

Effiong, J. (2011). Changing pattern of land use in the Calabar river Catchment, south eastern Nigeria. Journal of Sustainable Development, 4(1), 92-102.

Egbai, O.O.; Ukata, S. U.; Ndik, E. J. ;Ewa, E.E. and Ubor, U.U. (2011). Assessment of soils susceptibility to erosion menace in Calabar Metropolis, Cross River State, Nigeria. Journal of Human Ecology, 36 (3), 205-209.

Jackson, K. P.; Hart, L.; Adekunle, I. and Nkwunonwo, U.C. (2012). Investigating the changes in the coastal environment of Okrika, Rivers State between 1986 and 2007 using remote sensing and GIS techniques, $47^{\text {th }}$ Annual General Meeting and Conference of Nigerian Institution of Surveyors, 25-29 June 2012.

James L. A., and Lecce S. A. (2013). Impacts of Land-Use and Land-Cover Change on River Systems. In: John F. Shroder (ed.) Treatise on Geomorphology, ( 9), 768-793. San Diego: Academic Press.

Nduji, N. N.; Nnam, V. C. and Ekpete, B. O. (2012). Gully erosion monitoring of Iyioku river, Nike, Enugu State, Nigeria, using remote sensing, $47^{\text {th }}$ Annual General Meeting and Conference of Nigerian Institution of Surveyors, 25-29 June, 2012.

Ogar, T. O. (2006). Forest Distribution from Logging Operations in Etung Local Government Area, Cross River State. M.Sc Thesis, University of Port Harcourt.

Oyegun, C. U; Umeuduji, J. E; Abali, T. P and Abua, M. A (2016). Land cover dynamics in Calabar river catchment, Cross River State, Nigeria. Journal of Research in Environmental and Earth Science, 2 (9), 11-18.

United Nations Development Programme, UNDP (1995). Studies on erosion, flood and landslide in Abia, Akwa Ibom, Cross River and Imo States. Baseline Report, 1995, 3, 10-15.

\section{Copyrights}

Copyright for this article is retained by the author(s), with first publication rights granted to the journal.

This is an open-access article distributed under the terms and conditions of the Creative Commons Attribution license (http://creativecommons.org/licenses/by/4.0/) 